Meta

Journal des traducteurs

Translators' Journal

SORIANO-BARABINO, Guadalupe (2016): Comparative Law for

Legal Translators. Bern: Peter Lang, 206 p.

\title{
Jaakko Husa
}

Volume 63, numéro 1, avril 2018

URI : https://id.erudit.org/iderudit/1050533ar

DOI : https://doi.org/10.7202/1050533ar

Aller au sommaire du numéro

Éditeur(s)

Les Presses de l’Université de Montréal

ISSN

0026-0452 (imprimé)

1492-1421 (numérique)

Découvrir la revue

Citer ce compte rendu

Husa, J. (2018). Compte rendu de [SORIANO-BARABINo, Guadalupe (2016):

Comparative Law for Legal Translators. Bern: Peter Lang, 206 p.] Meta, 63(1),

275-276. https://doi.org/10.7202/1050533ar

Ce document est protégé par la loi sur le droit d'auteur. L'utilisation des services d'Érudit (y compris la reproduction) est assujettie à sa politique d'utilisation que vous pouvez consulter en ligne.

https://apropos.erudit.org/fr/usagers/politique-dutilisation/
Cet article est diffusé et préservé par Érudit.

Érudit est un consortium interuniversitaire sans but lucratif composé de l’Université de Montréal, l'Université Laval et l'Université du Québec à Montréal. Il a pour mission la promotion et la valorisation de la recherche. https://www.erudit.org/fr/ 
Soriano-Barabino, Guadalupe (2016): Comparative Law for Legal Translators. Bern: Peter Lang, $206 \mathrm{p}$.

Law is essentially and inseparably interwoven with language. In turn, law and language are both cultural phenomena that can be conceived only if their contexts are taken into account. There are virtually no contemporary legal philosophers who would not hold both of these assumptions as having a sound basis. However, for comparative law as a field of study, the role of language is an eternal obstacle and a challenge. In fact, legal translation has always been regarded as one of the essential questions of comparative law (Pozzo 2012). Likewise, translating legal texts has always been a somewhat specific ordeal for translators. Soriano-Barabino's book attempts to clarify and discuss the key questions related to legal translating and especially the role of comparative law for legal translators.

This book is not a study of legal translation, but rather introduces comparative law's theories and basic questions for translators of legal documents. In practice, most of the book deals with comparative law but in such a manner that is intended to be especially useful for legal translators, translators-to-be, and translator trainers. Accordingly, comparative lawyers and comparative legal scholars are less likely to find the comparative law discussion in this book particularly useful, but, then again, that is not what the book aims for.

The volume is divided into four main parts. The first part seeks to place comparative law and legal translation into perspective by first defining comparative law's development, nature, object of study and methodology (chapter 1); and second, by offering a brief overview of the main legal families of the world (Chapter 2). The second part (Chapters 3-6) deals with the civil law tradition by introducing the legal systems of Italy (chapter written by Angela Carpi), France, Spain, and Germany (chapter written by Rafael Adolfo Zambrana Kuhn). The basic structure of discussion for each of these legal systems is similar: historical evolution, the organization of law (distinction between public and private law), the court system, and the legal profession. The underlying idea for the second part is not to provide full accounts, but rather, to make it possible for a translator to "be able to grasp the main features of these legal systems and have the necessary competence to do research and find the information needed to correctly understand source texts." (p. 35)

The third part examines the common law tradition covering England and Wales (Chapter 7), the United States (Chapter 8), and Ireland (Chapter 9). As already pointed out above, the aim is not to provide full accounts of these legal systems but to introduce such main aspects as may be particularly useful for translators. The structure for presenting these common law systems is basically similar to the one used while discussing the civil law systems in the previous part. Yet, the history of the English law is left out because it is already shortly explained in chapter 2 when the development and origins of the common law system are elucidated. Chapter 7 does not take into account the possible ramifications of the United Kingdom's separation from the European Union but it does contain an explanatory footnote (p. 101) informing the reader about the looming separation and its possible effects.

Although the individual chapters about legal systems are very brief, they manage to offer surprisingly decent overviews. Moreover, these chapters contain an unexpected amount of useful native legal terminology. Especially the tables of court systems (jurisdiction, structure and levels of courts) with English translations seem quite useful both for translators and comparative lawyers.

The fourth and final part assumes a more practical approach by trying to merge legal translation and comparative law. Chapter 10 first discusses the training of legal translators by outlining the translation competence in legal translation, after which it deals with the age old question of should we train lawyer-linguists or legal translators. It is here that this book actually chooses to take a stand and not to limit itself to the confines of a traditional textbook. First, it is explained why professional translators should ideally be experts in translation and in legal matters, both in the source and target legal systems they work with. Second, because knowing several legal systems is an exceptionally tall order for anyone, the author continues by stating that one does not really need to "pursue two university degrees as lawyers and translators, and it would be more realistic to offer interdisciplinary legal translator training programmes into which law and translation courses are integrated." (p. 153)

Importantly, it is not suggested that translators ought to study national legal systems as such but, rather, that in the training of legal translators one should rely on comparative law instead. This is a valuable point because it is often suggested that translators ought to be lawyers, yet the obvious problem with this approach is, as this book makes clear, that it epistemologically binds the translator into one system. This is counterproductive if the aim is to transfer legal knowledge from one system to another. Such an argument is plausible because legal translators do not only translate words but they are obliged to take into account culturespecific factors too (McAuliffe 2014).

The final chapter (11) considers how comparative law may be a useful instrument in the practice of translating legal texts. This chapter describes 
and offers examples of certain strategies and techniques considered essential for the translation of legal texts.

For example, coincident with the search for equivalents, such techniques as transcription, borrowing, and adaptation are mentioned. The final part also puts forward a small battery of exercises aimed at raising awareness concerning different textual conventions in different legal systems.

Comparative Law for Legal Translators fulfils its claim - that is, it offers an introduction to comparative law for translators of legal documents. Its main argument seems to be to underline the importance of comparative law knowledge and skills for legal translation and for training of legal translators. There are scant comparative law texts by translators. This book seems to fill a gap in the literature. Accordingly, it makes a contribution to the field of legal translation, although its take on comparative law is a bit narrow and seems to rely on somewhat outdated literature. Much of the discussion and debate of this century has not found its way into this book. On the other hand, because the main focus is to offer an introduction to legal translators this scholarly narrowness is not really a problem for this volume. Yet this book could have said something about the significance of the transnationalisation of law for legal translation because these new developments raise challenges for both comparative law and legal translation (Kjær 2014).

To conclude, the book serves well as a basic textbook in training of legal translators. It is also of interest for comparative lawyers because it offers the "other side" of how to deal with foreign legal documents. In other words, this volume points out details and discusses translation strategies and techniques that may be overlooked by comparative lawyers.

JAAKKo Husa

University of Helsinki, Helsinki, Finland

\section{REFERENCES}

KJÆR, Anne Lise (2014): New challenges to the theory of legal translation: transnational legal communication and the autonomization of international law. The Translator. 20(3):430436.

McAuliffe, Karen (2014): Translating Ambiguity. The Journal of Comparative Law. 9(2):65-87.

Pozzo, Barbara (2012): Comparative law and language. In: Mauro Bussani and Ugo MatteI, eds. The Cambridge Companion to Comparative Law. Cambridge: Cambridge University Press, 88-102. 